\title{
RANCANG BANGUN SISTEM INFORMASI GEOGRAFIS PEMETAAN PENYEBARAN PENYAKIT STUNTING DI KABUPATEN MALANG
}

\author{
Ade Saputra $^{1}$, Yoyok Seby Dwanoko ${ }^{2}$, Aan Jelli Priana ${ }^{3}$ \\ Sistem Informasi, Universitas Kanjuruhan Malang ${ }^{1,2,3}$ \\ ade.saputra.231198@gmail.com¹ ${ }^{1}$ yoyokseby@unikama.ac.id², ms.aanjp@gmailcom ${ }^{3}$
}

\begin{abstract}
Abstrak. Sistem informasi geografis pemetaan penyebaran stunting ini dibangun untuk membantu pihak instansi Dinas Kesehatan Kabupaten Malang untuk mendapatkan informasi penderita stunting di Kabupaten Malang. Selama ini untuk mendapatkan informasi keberadaan dari titik lokasi penderita stunting hanya sebatas pembicaraan oleh warga setempat sehingga terkesan lambat dalam melakukan tindakan penanganan. Penelitian ini bertujuan membuat sistem informasi geografis (SIG) yang dapat memberikan informasi tentang penyebaran penderita stunting secara visual di Kabupaten Malang. Serta menampilkan penyajian informasi rute menuju lokasi penderita stunting. Peneliti menggunakan Sistem Informasi Geografis (SIG) untuk menampilkan geografis daerah dan menampilkan titk lokasi dari penderita stunting dan menggunakan model prototipe untuk perancangan sistem. Untuk pengujian sistem menggunakan pengujian black box dan User Acceptance Testing (UAT). Dari pengujian black box diketahui seluruh fungsi sisitem dibuat berjalan sesuai dengan yang diinginkan. Kemudian dari hasil pengujian User Acceptance Testing (UAT) didapatkan hasil perhitungan rata-rata $92,26 \%$ yang artinya sistem bekerja dengan baik dan dapat diterima oleh user di Dinas Kesehatan Kabupaten Malang.

Kata Kunci: Sistem Geografis, Stunting, Prototipe.
\end{abstract}

\section{PENDAHULUAN}

Stunting merupakan dimana anak atau balita (bayi di bawah lima tahun) memiliki kondisi gagal tumbuh pada dikarenakan kondisi terlalu pendek untuk usianya. Faktor penyebab terjadinya stunting dikarenakan pengasuhan yang kurang baik, kurangnya pelayanan kesehatan bagi ibu hamil, kurangnya pengetahuan keluarga terhadap makanan yang bergizi dan susahnya mendapatkan akses ke air bersih dan sanitasi (Kemenkes, 2018).

Dinas Kesehatan Kabupaten Malang merupakan salah satu instansi yang mengawasi dan mengendalikan perencanaan program kesehatan termasuk penekanan penyebaran penyakit khususnya stunting. Saat ini Dinas Kesehatan Kabupaten Malang memiliki jumlah penderita stunting yang bisa dikatakan cukup rawan. Dilihat dari penyajian informasi data penderita stunting di Dinas Kesehatan Kabupaten Malang, jumlah penderita stunting pada tahun 2018 berjumlah 58\%. Kemudian ditinjau dari tahun 2019 tingkat penderita stunting berjumlah $69,23 \%$ jika tidak ditangani secara serius maka kasus setunting akan semakin meningkat. Saat ini instansi Dinas Kesehatan Kabupaten Malang belum memiliki sistem atau alat bantu untuk menampilkan geografis wilayah kecamatan dan desa secara visual. Serta tidak adanya penyajian informasi yang menampilkan rute menuju lokasi penderita stunting. Selama ini untuk mendapatkan informasi keberadaan dari titik lokasi penderita stunting hanya sebatas pembicaraan oleh warga setempat sehingga terkesan lambat dalam melakukan tindakan penanganan.

Untuk melakukan pemetaan maka dipilih Sistem Informasi Geografis (SIG) untuk membantu instansi Dinas Kesehatan Kabupaten Malang dalam pencarian segala informasi tentang penyakit stunting terutama dalam lingkup Kabupaten Malang. Menurut (Sukiyah, 2017) Sistem Informasi Geografis (SIG) adalah suatu sistem di mana data grafik dan atribut dapat disimpan dalam ruang sesuai dengan keinginan pengguna. Menurut (Nirwansyah, 2018) Komponen yang digunakan dalam SIG merupakan komponen pendukung utama, dan penunjang komponen tersebut juga saling berkontribusi dalam menghasilkan output. Komponen tersebut 
terdiri dari hardware, software, brainware, data dan metode. Penggunaan SIG dalam bidang kesehatan dapat digunakan untuk menyediakan data atribut dan data spasial sehinga dapatmenggambarkan sebaran penyakit penderita, pola atau model sebaran penyakit serta fasilitas pendukungnya (Waskito \& Kresnowati, 2017). Kemudian menurut (Faqih \& Avisha, 2019) Saat menggunakan GIS untuk menggambar peta kasus penyakit, SIG dapat memberikan layanan bagi pasien, termasuk layanan akselerasi, pencarian data, pembuatan laporan dan penyediaan informasi yang lebih akurat, yang membawa manfaat dan kemudahan. Dengan menggunakan Sistem Informasi Geografis (SIG) maka data dapat di visualisasikan atau dipetakan sesuai dengan sebaran dalam lingkup daerah kecamatan hingga sampai ke daerah desa. Penelitian ini bertujuan membuat sistem informasi geografis (SIG) yang dapat memberikan informasi tentang penyebaran penderita stunting secara visual di Kabupaten Malang. Serta menampilkan penyajian informasi rute menuju lokasi penderita stunting.

Pada Penelitian (Waskito \& Kresnowati, 2017) bertujuan untuk menentukan sepuluh penyakit teratas di Puskesmas Mojosongo berdasarkan sistem informasi geografis (SIG) dan menggambar peta sebaran sepuluh penyakit teratas tersebut.

Pada penelitian sebelumnya SIG digunakan untuk mengetahui tingkat penyebaran demam berdarah di Wilayah Jombang menggunakan model waterfall (Bahtiar \& Sifaunajah, 2018).

Sementara itu, penelitian yang dilakukan oleh (Wibowo dkk, 2016) SIG memberikan informasi tentang peta penularan nyamuk demam berdarah di wilayah Istimewa Yogyakarta melalui visualisasi informasi berdasarkan kondisi geografis wilayah tersebut.

Penelitian yang dilakukan (Yusuf \& Kaniawulan, 2015) yaitu membangun sebuah sistem yang mengambil objek dari data lokasi fasilitas olahraga pada Kecamatan Purwakrta berdasarkan titik koordinat lokasi perangkat bergerak (mobile) yang didapatkan dari GPS dan peta yang memakai Google Maps API, serta menggunakan GOOGlE Maps Direction untuk menentukan rute menggunakan model prototipe.

\section{METODE PENELITIAN}

\section{A. Model Penelitian}

Model penelitian pengembangan yang digunakan dalam penelitian ini didasarkan pada metode pengembangan perangkat lunak prototipe yang terbagi menjadi lima tahap (Pressman \& Maxim, 2015). Sebuah prototipe versi awal sofware yang dipakai untuk membuat suatu sistem informasi geografis (SIG) yang dapat memberikan kemudahan dalam mengetahui informasi mengenai penyebaran stunting dan menampilkan rute lokasi penderita stunting di Kabupaten Malang.

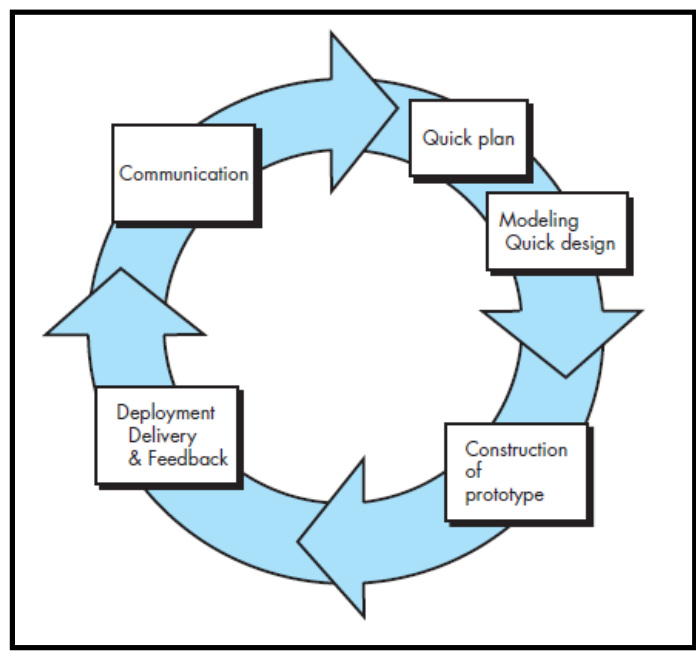

Gambar 1 Model Prototipe (Pressman \& Maxim, 2015) 


\section{Communication.}

Pada tahap communication melakukan pengumpulan kebutuhan melakukan pertemuan antara peneliti dan Kepala Bidang Kesehatan Masyarakat Dinas Kesehatan Kabupaten Malang. Tujuan dari tahapan ini adalah untuk mengetahui kebutuhan dasar perangkat sistem informasi geografis, yang nantinya akan menghasilkan dokumen kebutuhan pengguna, atau dapat dikatakan data yang berkaitan dengan sistem yang dihasilkan sesuai kebutuhan Dinas Kesehatan Kabupaten Malang.

\section{Quick Plan}

Pada tahap perencanaan cepat (quick plan) akan dilakukan desain cepat yang mewakili perangkat lunak dan perangkat keras, desain ini akan menjadi dasar dari prototipe. Peneliti melakukan analisis kebutuhan untuk membangun sistem yang dibutuhkan oleh Dinas Kesehatan Kabupaten Malang.

\section{Modelling Quick Design}

Pada tahap ini analisis akan menggunakan UML untuk perancangan sistem sebagai dasar perancangan aplikasi. Menurut Braun, dkk dalam (Sutejo, 2016) Unified Modeling Language (UML) adalah alat yang digunakan untuk memvisualisasikan dan merekam hasil analisis dan desain, yang berisi sintaks yang digunakan dalam visualisasi pemodelan sistem. Dalam hal ini programmer menggunakan bahasa pemrograman lealet.js dan aplikasi Quantum Gis untuk membuat peta Kabupaten Malang.

(Bahtiar \& Sifaunajah, 2018) Leaflet.js adalah perpustakaan Open Source JavaScript yang membantu pembuatan peta pada halaman web mudah.

(Nurrizqi, 2017) Quantum GIS atau lebih dikenal dengan QGIS merupakan salah satu perangkat lunak Sistem Informasi Geografis (SIG) berbasis open source dengan lisensi di bawah General Public License (GNU) yang dapat dijalankan dalam berbagai sistem operasi.

\section{Construction Of Prototype}

Pembangunan tahap prototipe (construction of prototype) dilakukan setelah kegiatan analisis dan perancangan. Bagian ini akan menjelaskan kegiatan yang dilakukan selama tahap pengkodean sistem operasi, implementasi pemrograman (programming).

\section{Deployment delevery \& feedback}

Selanjutnya tahapan Deployment delevery \& feedback dimana sistem yang telah dibuat sesuai dengan keinginan dari pelanggan, kemudian melakukan pengujian (testing) menggunakan Black Box dan UAT Dengan cara ini pneliti dapat menentukan apakah sistem yang dibuat dapat diterima.

\section{B. Instrumnet Pengumpulan Data}

Dalam penelitian ini alat pengumpulan data yang digunakan untuk membuat sistem informasi geografis meliputi penelitian kepustakaan, observasi dan wawancara. Teknik penelitian literatur digunakan untuk pengumpulan data berupa dokumen pendukung dan uraian tentang teori, jurnal peneliti lain, buku dan pengumpulan data dari Instansi Dinas Kesehatan Kabupaten Malang. Observasi dan Wawancara dilakukan utnuk pengumpulan data beberapa masalah yang berkaitan dengan penyebaran kasus penyakit stunting dimana untuk mengetahui penyebaran stunting di Kabupaten Malang, data yang dikumpulkan berupa data penderita stunting, data kecamatan, data desa dan data geografis pendrita stunting. Pada tahap wawancara dilakukan kepada Kepala Bidang Kesehatan dan Staf Pelayanan Kesehatan di Dinas Kebupaten Malang bahwa tidak adanya sistem untuk mendapatkan informasi penderita stunting yang menampilkan lokasi penderita dan rute menuju lokasi dari penderita stunting secara visual.

\section{Teknik Analisis Data}

Penelitian ini menggunakan dua teknik analisis data di antaranya menggunakan User Acceptance Test (UAT) untuk menganalisis apakah sistem tersebut sesuai keinginan pengguna. (Borobudur, 2020) User Acceptance Test (UAT) adalah pengujian yang dilakukan user untuk 
mengeluarkan dokumen hasil pengujian, yang dapat digunakan sebagai bukti bahwa perangkat lunak telah diterima dan persyaratan terpenuhi.

Kemudian untuk menguji sisitem apakah sisitem berjalan dengan lancar menggunakan black box. (Pasaribu dkk, 2019) Pengujian black box digunakan untuk mengukur fungsionalitas suatu program dengan memastikan bahwa setiap menu dan fungsi dapat berfungsi dengan baik.

\section{HASIL DAN PEMBAHASAN}

\section{A. Perancangan Design Sistem}

Penelitian ini menggunakan UML (Unified Modeling Language) sebagai perancangan sisitem untuk mempermudah proses penggambaran desain sistem dari awal pembuatan prototipe. Perancangan dimulai dari pembuatan Use case Diagram Utama, Sub use case, Activity diagram, Sequence diagram dan Class diagram. Dapat dilihat pada gambar 2 Use case Diagram Utama.

1. Use case Diagram Utama

Use Case Diagram Utama mempresentasikan semua kebutuhan yang telah direncanakan dalam tahap perancangan cepat (quick plan).

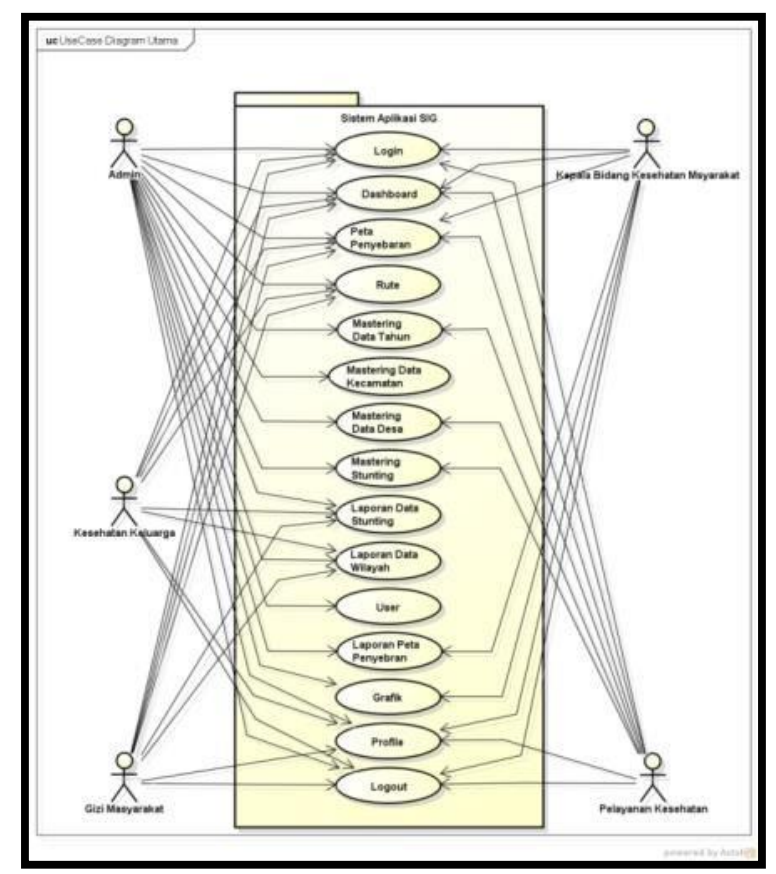

Gambar 2 Use Case Diagram Utama

Penjelasan Use Case Diagram Utama sebagai berikut:

a. Login digunakan oeh user untuk masuk pada menu utama dengan cara memasukan email dan pasword.

b. Peta Penyebaran digunakan oleh user untuk melihat penyebaran stunting di Kabupaten Malang berdasarkan kecamatan dan desa.

c. Rute digunakan untuk melihat rute menuju lokasi penderita stunting.

d. Mastering Data Tahun digunakan untuk mengelola data tahun penyebaran.

e. Mastering Data Kecamatan digunakan untuk mengelola data kecamatan yang ada di Kabupaten Malang.

f. Mastering Data Desa digunakan untuk mengelola data desa yang ada di Kabupaten Malang.

g. Mastering Data Stunting digunakan untuk mengelola data stunting yang ada di Kabupaten Malang.

h. Laporan Data Wilayah digunakan untuk milahat laporan jumlah penyebaran data stunting berdasarkan kecamatan dan desa.

i. Laporan Data Stunting digunakan untuk melihat jumlah penderita stunting pertahun di Kabupaten Malang. 
j. Grafik digunakan oleh user untuk melihat laporan berupa grafik penyebaran stunting berdasarkan perbandingan tahun dan kategori.

\section{Class Diagram}

Pada penelitian ini perancangan class diagram terdiri dari 6 tabel yang saling berkaitan. Bisa di lihat pada gambar 3 class diagram.

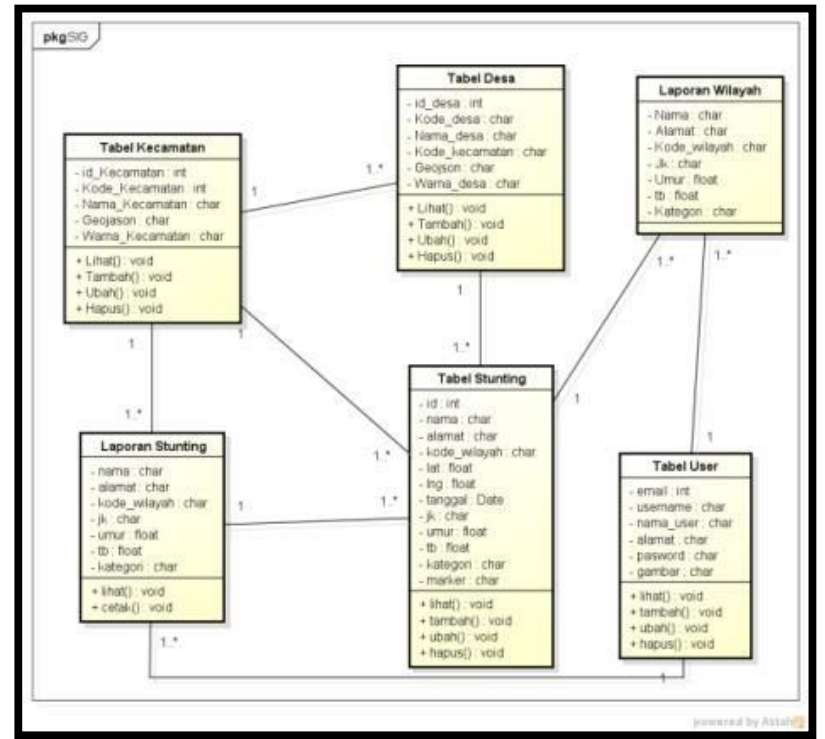

Gambar 3 Class Diagram

Penjelasan class diagram sebagai berikut:

a. Tabel Kecamatan digunakan untuk menyimpan data kecamatan.

b. Tabel Desa digunakan untuk menyimpan data kecamatan.

c. Tabel Stunting digunakan untuk menyimpan data penderita stunting.

d. Tabel Laporan Data Wilayah digunakan untuk menampilkan laporan penderita stunting berdasarkan kecamatan dan desa.

e. Tabel Laporan Data Stunting digunakan untuk menampilkan laporan data penderita stunting berdasarkan tahun penyebaran.

f. Tabel User digunakan untuk menyimpan data user atau pengguna sisitem informasi geografis.

\section{B. Hasil Perancangan Sistem}

1. Halaman Utama

Tampilan Halaman Utama (homepage) merupakan tampilan awal saat mengunjungi website GIS untuk memetakan sebaran stunting di Kabupaten Malang. Berikut adalah tampilan dari halaman utama terdapat pada gambar 4:

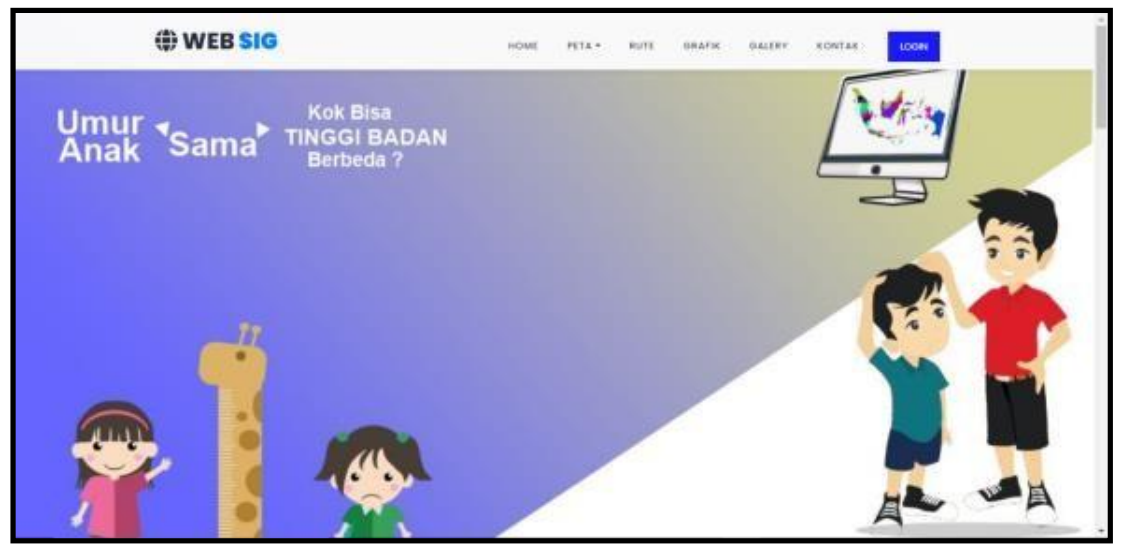

Gambar 4 Tampilan Halaman Utama 


\section{Halaman Login}

Halaman login digunakan user dari Dinas Kesehatan Kabupaten Malang. Berikut tampilan dari halaman login:

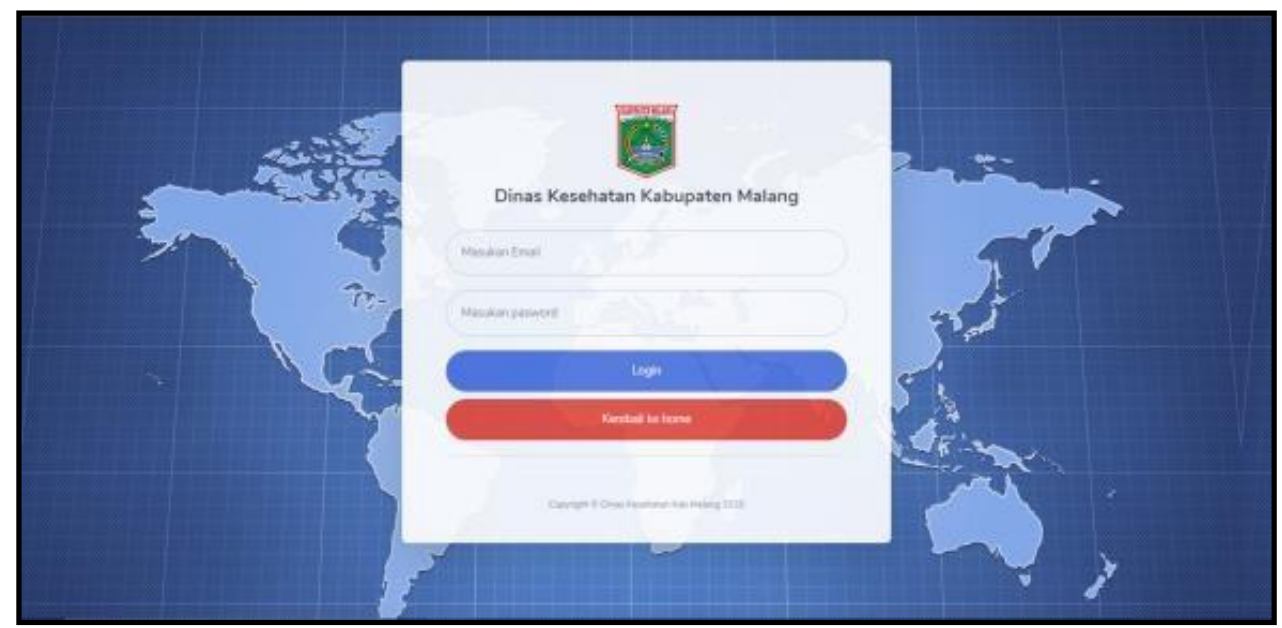

\section{Gambar 5 Halaman Login}

3. Peta Penyebaran

Halaman peta penyebaran digunakan untuk menampilkan wilayah administrasi Kabupaten Malang dan menampilkan jumlah penderita stunting berdasarkan kecamatan dan desa. Berikut tampilan dari peta penyebaran:

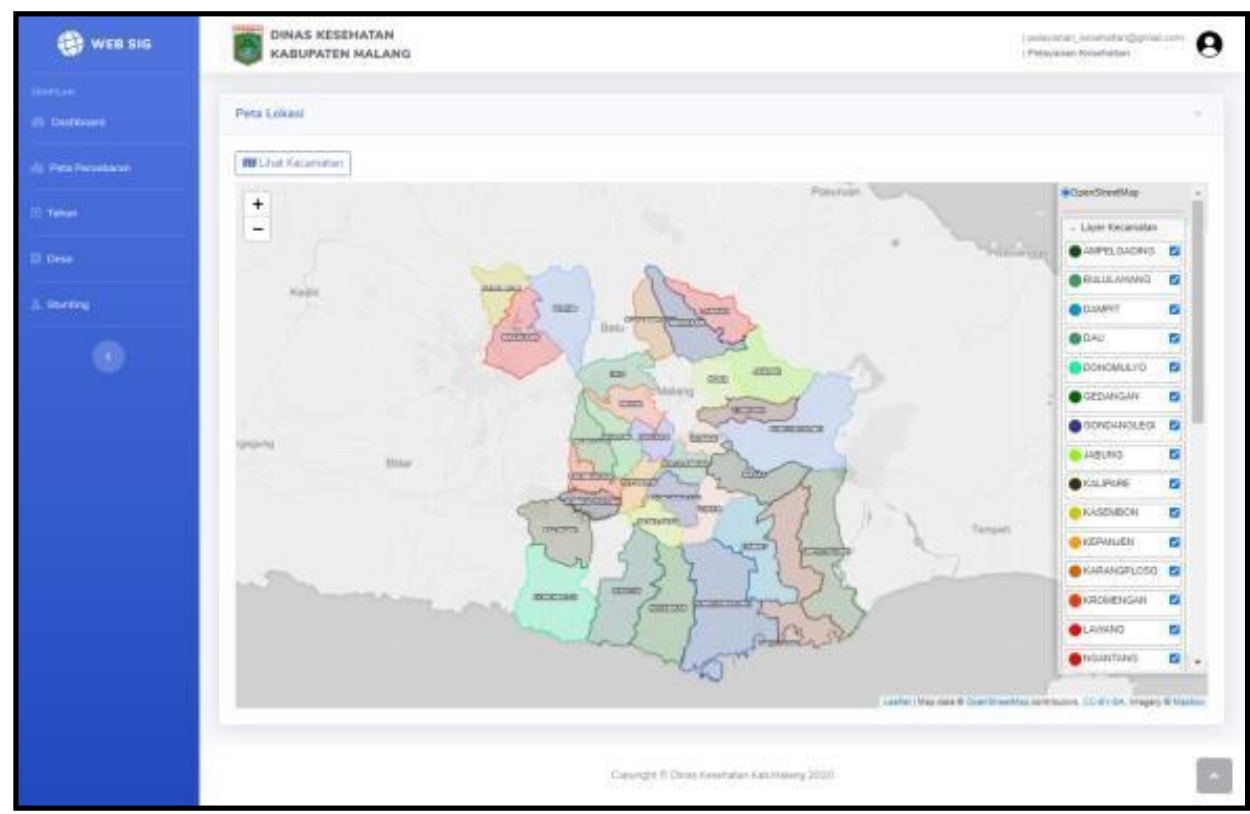

Gambar 6 Peta Penyebaran

4. Mastering Data Kecamatan

Mastering data kecamatan digunakan untuk mengolah data wilayah administrasi kecamatan di Kabupaten Malang. Berikut tampilan dari mastering data kecamatan: 


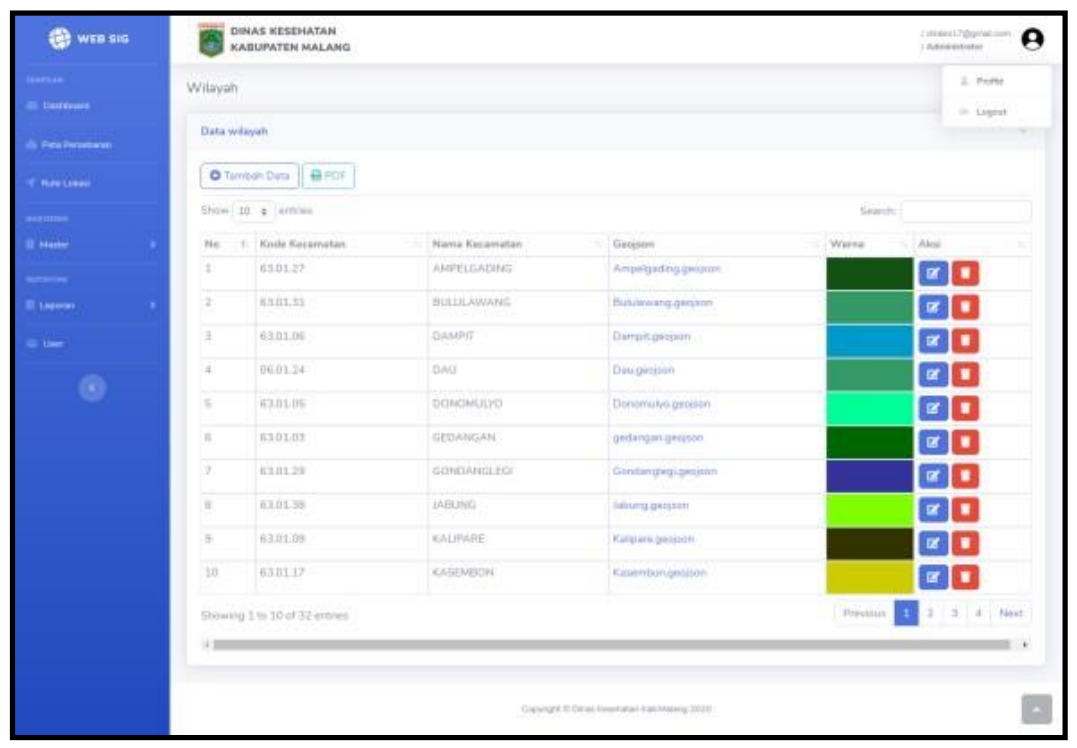

Gambar 7 Mastering Data Kecamatan

5. Laporan Data Stunting

Tampilan laporan data stunting digunakan untuk melihat jumlah data pendrita stunitng berdasarkan kecamatan dan tahun penyebaran. Berikut tampilan laporan data stunting:

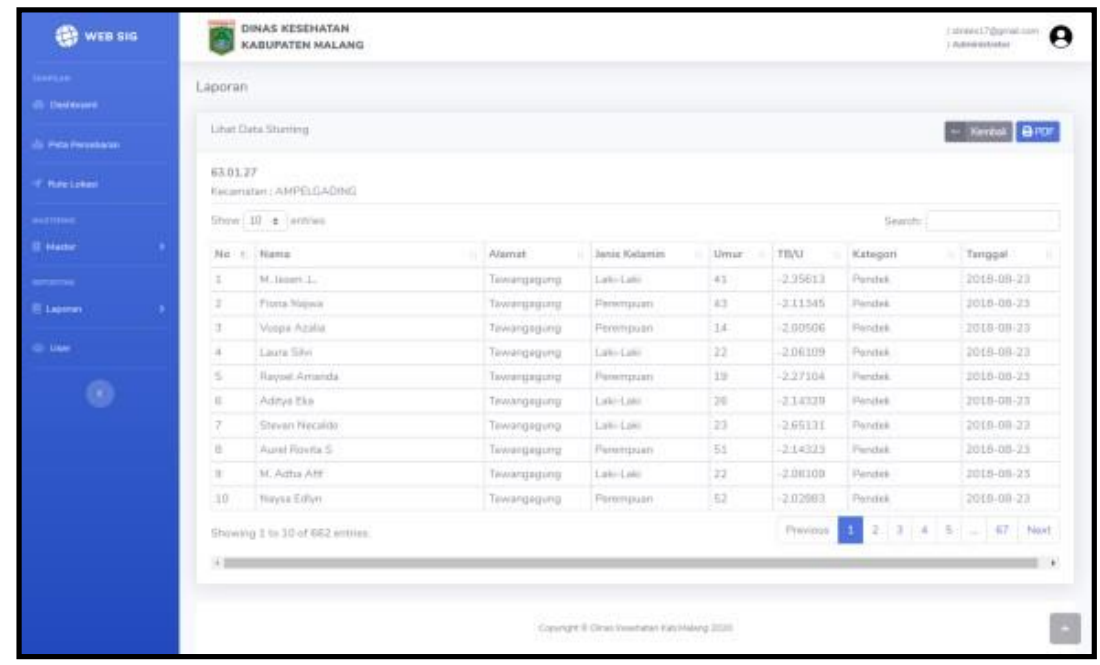

Gambar 8 Halaman Laporan Data Stunting

6. Laporan Grafik

Laporan grafik digunakan untuk menampilkan informasi data persebaran penderita stunting berdasarkan perbandingan tahun dan menampilkan informasi data kategori stunting. Berikut tampilan halaman laporan grafik: 


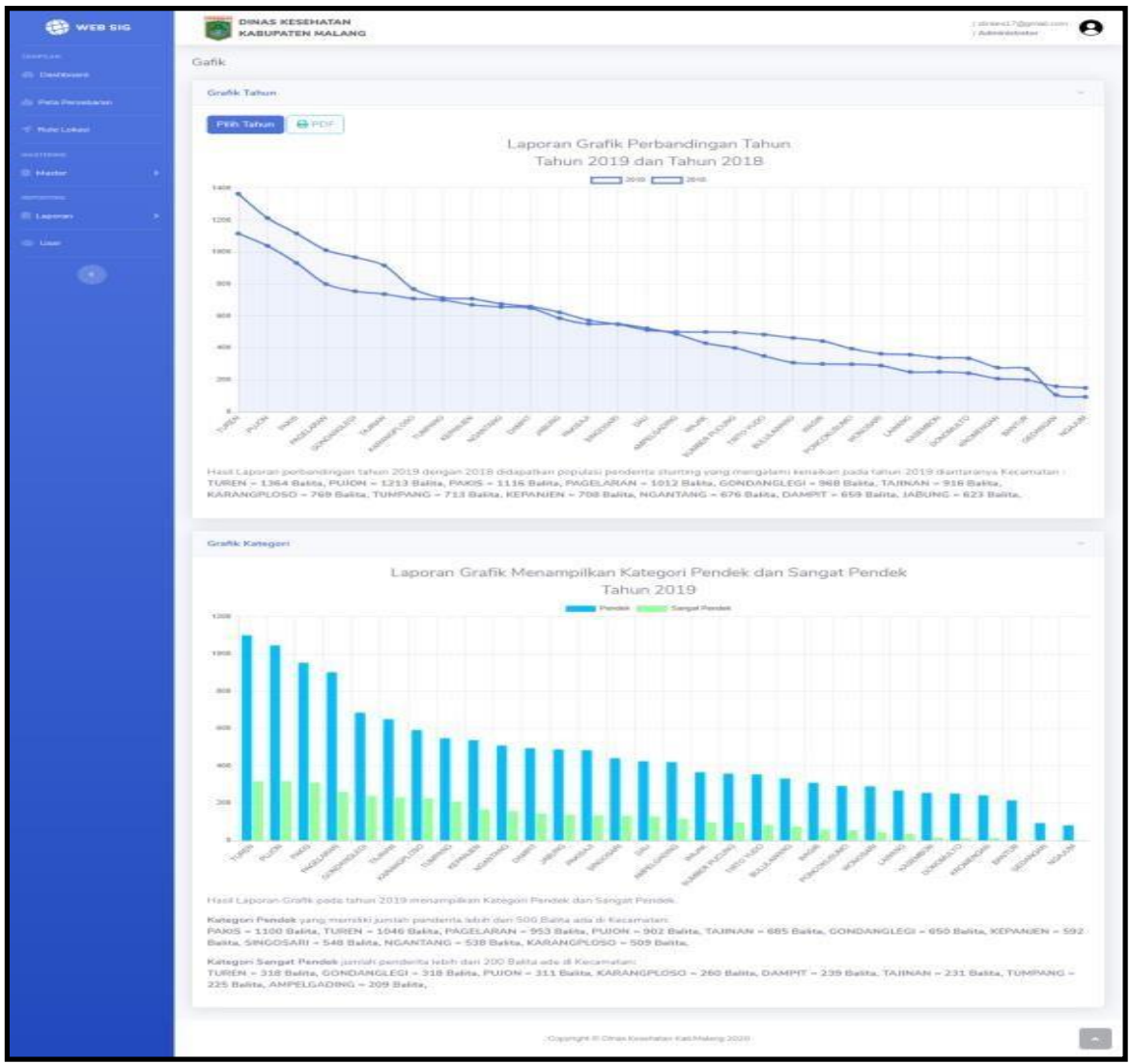

Gambar 9 Halaman Laporan grafik

\section{Pengujian Sistem}

Pengujian sistem pada tahapan ini menggunakan black box testing dan user acceptance testing (UAT). Pengujian dilakuakn agar membuktikan bahwa semua objek dalam sistem bekerja seperti yang di inginkan. Langkah pengujian ini diselesaikan dengan menguji semua fungsi di setiap halaman.

1. Pengujian Dengan Black Box

Tabel 4.12 Pengujian Produk Black box

\begin{tabular}{|c|c|c|c|c|}
\hline No & Fungsi & Pengujian & Hasil yang Diharapkan & Keterangan \\
\hline 1 & Login & $\begin{array}{l}\text { Memasukkan username dan } \\
\text { password sesuai dengan data } \\
\text { actor. }\end{array}$ & $\begin{array}{l}\text { Masuk ke halaman } \\
\text { dashboard pengguna }\end{array}$ & Sesuai \\
\hline 3 & Peta Penyebaran & $\begin{array}{lr}\begin{array}{l}\text { Melihat Data Penyebaran } \\
\text { Stunting }\end{array} & \text { berdasarkan } \\
\text { wilayah kecamatan dan desa. }\end{array}$ & $\begin{array}{l}\text { Menampilkan informasi } \\
\text { Penyebaran stunting }\end{array}$ & Sesuai \\
\hline 4 & Rute & $\begin{array}{l}\text { Melihat titik dan rute lokasi } \\
\text { penderita stunting. }\end{array}$ & $\begin{array}{ll}\text { Menampilkan } & \text { jalur/rute } \\
\text { menuju } & \text { penderita } \\
\text { stunting } & \\
\end{array}$ & Sesuai \\
\hline 5 & $\begin{array}{l}\text { Mastering Data } \\
\text { Tahun }\end{array}$ & $\begin{array}{l}\text { Menginputkan data tahun } \\
\text { berupa id dan tahun. }\end{array}$ & $\begin{array}{l}\text { Menampilkan data tahun } \\
\text { berdasarkan id. }\end{array}$ & Sesuai \\
\hline 6 & $\begin{array}{l}\text { Mastering Data } \\
\text { Desa }\end{array}$ & $\begin{array}{l}\text { Menginputkan data desa } \\
\text { berupa kode desa, kode } \\
\text { kecamatan, nama desa, } \\
\text { latittute, longittute, geojson } \\
\text { dan warna. }\end{array}$ & $\begin{array}{l}\text { Menampilkan data desa } \\
\text { berdasrkan kode desa. }\end{array}$ & Sesuai \\
\hline 7 & $\begin{array}{l}\text { Matering } \\
\text { Kecamatan }\end{array}$ & $\begin{array}{l}\text { Menginputkan } \\
\text { kecamatan berupa } \\
\text { kecamatan, }\end{array}$ & $\begin{array}{l}\text { Menampilkakn data } \\
\text { kecamatan berdasarkan } \\
\text { kode kecamatan. }\end{array}$ & Sesuai \\
\hline
\end{tabular}




\begin{tabular}{|c|c|c|c|c|}
\hline & & $\begin{array}{l}\text { kecamatan, latittute, } \\
\text { longittute, geojson dan } \\
\text { warna. }\end{array}$ & & \\
\hline 8 & $\begin{array}{l}\text { Mastering Data } \\
\text { Stunting }\end{array}$ & $\begin{array}{l}\text { Menginputkan data } \\
\text { penderita stunting berupa } \\
\text { nama, alamat, kecamatan, } \\
\text { latittute, longittute jenis } \\
\text { kelamin, tanggal, umur, dan } \\
\text { kategori. }\end{array}$ & $\begin{array}{lr}\text { Menampilkan } & \text { data } \\
\text { penderita } & \text { stunting } \\
\text { berdasarkan } & \text { kecamatan } \\
\text { dan kesa. } & \end{array}$ & Sesuai \\
\hline 9 & $\begin{array}{l}\text { Laporan } \\
\text { Wilayah }\end{array}$ & $\begin{array}{l}\text { Melihat jumlah penderita } \\
\text { stunting berdasarkan } \\
\text { kecamatan dan tahun } \\
\text { penyebaran. }\end{array}$ & 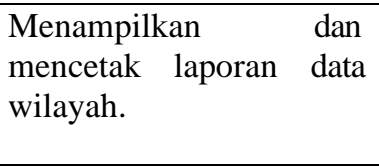 & Sesuai \\
\hline 10 & $\begin{array}{l}\text { Laporan } \\
\text { Stunting }\end{array}$ & $\begin{array}{l}\text { Melihat data penderita } \\
\text { stunting } \\
\begin{array}{l}\text { kecamatan } \\
\text { kerdasarkan } \\
\text { penyebaran. }\end{array}\end{array}$ & $\begin{array}{l}\text { Menampilkan dan } \\
\text { mencetak data stunting. }\end{array}$ & Sesuai \\
\hline 11 & $\begin{array}{l}\text { Laporan Peta } \\
\text { Penyebaran }\end{array}$ & $\begin{array}{l}\text { Melihat peta } \text { penyebaran } \\
\text { stunting } \\
\text { kecamatan } \\
\text { dikategorikan berdasarkan } \\
\text { warna. }\end{array}$ & $\begin{array}{l}\text { Menampilkan } \\
\text { mencetak } \\
\text { penyebaran. }\end{array}$ & Sesuai \\
\hline 12 & Grafik & $\begin{array}{l}\text { Melihat data penderita } \\
\text { stunting } \\
\text { grafik menggunakan } \\
\text { perbandingan tahun. }\end{array}$ & $\begin{array}{l}\text { Menampilkan dan } \\
\text { mencetak laporan grafik. }\end{array}$ & Sesuai \\
\hline
\end{tabular}

2. Pengujian Dengan User Acceptance Testing (UAT)

Berdasarkan hasil uji sistem dengan User Acceptance Testing (UAT) didapatkan rata-rata untuk aspek sistem yaitu sebesar $90,94 \%$ menyatakan setuju bahwa sistem yang menampilkan peta informasi penyebaran stunting ini mudah dioperasikan dan sistem berjalan dengan semestinya. Pada aspek pengguna diketahui rata-rata 93\%, hal ini dapat disimpulkan bahwa bagi pengguna menu-menu pada sistem mudah dipahami, tampilan data ditampilkan dengan baik, dan hasil klasifikasi sudah sesuai. Sedangkan untuk aspek interaksi diketahui bahwa 93\% menyatakan setuju bahwa tampilan sistem mudah dipahami, hasil klasifikasi bisa dibaca dengan baik dan penyajian data tabel juga dapat terbaca dengan baik. Rata-rata UAT dari responden menyatakan bahwa tingkat kepuasan responden terhadap sistem yang telah dibuat mencapai $92,26 \%$.

\section{PENUTUP}

\section{A. Kesimpulan}

Peneliti menyimpulkan dari hasil penelitian sebagai berikut:

1. Telah berhasil membangun sistem informasi geografis pemetaan penyebaran stunting di Kabupaten Malang dengan menggunakan model prototipe yang dapat membantu Dinas Kesehatan Kabupaten Malang untuk menampilkan informasi penyebaran stunting di Kabupatrn Malang.

2. Sistem yang dihasilkan dapat menyajikan informasi rute atau jalur menuju penderita stunting di Kabupaten Malang berdasarkan wilayah kecamatan dan desa. Sedangkan data detail dan jumlah penderita stunting yang ada di setiap kecamatan dapat disajikan dalam bentuk tabel dan grafik. Informasi yang disajikan berdasarkan perbandingan tahun penyebaran dan kategori pendek dan sangat pendek. 
3. Sistem informasi geografis pemetaan penyebaran stunting ini dapat diterima berdasarkan hasil User Acceptance Testing (UAT) yang dilakukan dengan jumlah keseluruhan perhitungan rata-rata adalah $92,26 \%$.

\section{B. Saran}

Saran yang ditujukan untuk memberikan masukan yang lebih baik adalah sebagai berikut:

1. Rancangan sistem informasi geografis untuk sebaran penyakit stunting masih dimungkinkan dengan mengembangkan aplikasi berbasis perangkat bergerak (mobile), di mana informasi peta sebaran dapat ditampilkan pada perangkat bergerak (mobile).

2. Selain jenis penyakit stunting, perancangan sistem informasi geografis untuk penyebaran stunting juga dapat dikembangkan sehingga pengguna dapat secara bersamaan memperoleh informasi tentang penyebaran penyakit lain.

\section{DAFTAR PUSTAKA}

Bahtiar, N. D., \& Sifaunajah, A. (2018). Perancangan Sistem Informasi Geografis Penyebaran Penyakit Demam Berdarah Dengue Di Wilayah Jombang. Saintekbu, 10(1), 83-91. https://doi.org/10.32764/saintekbu.v10i1.165

Borobudur, U. (2020). DESAIN DAN PENERAPAN WEBSITE TATA KELOLA PERCETAKAN PADA CV APICDESIGN KREASINDO JAKARTA DENGAN METODE PROTOTYPING p-ISSN: 2579-5201 ( Print ). 4(1).

Faqih, H., \& Avisha, T. D. (2019). Geographic Information System Penyebaran Penyakit Puskesmas Kaligangsa Wetan. 6(1), 33-44.

kemenkes. (2017). Buku Ringkasan Stunting.

Nurrizqi, E. H. (2017). Modul pemetaan menggunakan qgis.

Pasaribu, A. F. O., Darwis, D., Irawan, A., \& Surahman, A. (2019). Sistem Informasi Geografis Untuk Pencarian Lokasi Bengkel Mobil Di Wilayah Kota Bandar Lampung. Jurnal Tekno Kompak, 13(2), 1. https://doi.org/10.33365/jtk.v13i2.323

Pressman, R., \& Maxim, B. (2015). REKAYASA PERANGKAT LUNAK: A PRACTITIONER'S APPROACH (8th ed.). McGraw-Hill Education, 2 Penn Plaza, New York, NY 10121.

Sutejo, S. (2016). Pemodelan UML Sistem Informasi Geografis Pasar Tradisional Kota Pekanbaru. Digital Zone: Jurnal Teknologi Informasi Dan Komunikasi, 7(2), 89-99. https://doi.org/10.31849/digitalzone.v7i2.600

Waskito, D. Y., \& Kresnowati, L. (2017). Jurnal Riset Kesehatan Masyarakat Mojosongo Kabupaten Boyolali Berbasis Sistem Informasi Geografis. 6(2), 7-16.

Wibowo, S., Lamato, M. S., Pradana, A. I., Aulawi, R. M., Indriyatmoko, T., \& Utami, E. (2016). Perancangan Sistem Informasi Geografis Penyebaran Penyakit Oleh Nyamuk di Provinsi Daerah Istimewa Yogyakarta. DutaCom Journal, 1(10), 59-68.

Yusuf, E. M., \& Kaniawulan, I. (2015). Pengembangan Prototipe Sistem Informasi Geografis Fasilitas Olahraga Berbasis Mobile (Studi Kasus Fasilitas Olahraga Di Kecamatan Purwakarta) Program Studi Teknik Informatika Sekolah Tinggi Teknologi Wastukancana Jalan Raya Cikopak Sadang No 54 Purwakarta. Riau Journal Of Computer Science, 1(1), $57-68$. 